\title{
Aristotelova numerická kategorizace předchůdců: Zdroje a důsledky
}

\section{Pavel Hobza}

I když je Aristotelés především systematickým filosofem, přesto důležitou část jeho myšlení představuje studium jeho předchůdců. Přitom se ovšem jak známo nejedná o historickou či historicky věrnou interpretaci (v tom smyslu, jak se na základě nejrůznějších hermeneutických kritérií a př́stupů snažíme my dnes dosahovat historické věrnosti či pravdy). Aristotelés své předchůdce chápal jako partnery aktuální filosofické diskuse, jejichž myšlení je možné, ba nutné neustále podrobovat kritické reflexi, a nikoli jako jakési antikvární poklady minulosti, k nimž by bylo nejen nezdvořilé, ale především nevědecké či nefilosofické přistupovat jinak než s uctivou otázkou, jak své myšlenky vlastně mysleli, respektive jak je jim třeba rozumět $\mathrm{v}$ dobovém intelektuálním a kulturním kontextu. Jinými slovy, názory předchůdců sloužily Aristotelovi jako neustále živá a aktuální inspirace jeho myšlení.

Protože rizika Aristotelova interpretačního př́stupu jsou zjevná a rovněž i dostatečně zdokumentovaná, nemělo 
by př́lišs smysl o nich znovu pojednávat. ${ }^{i}$ Navíc vzhledem $\mathrm{k}$ tomu, že Aristotelův interpretační př́istup $\mathrm{k}$ předchůdcům se mění kontext od kontextu (nebot' při zkoumání každého filosofického problému přistupuje Aristotelés ke svým předchůdcům vždy z poněkud odlišného interpretačního stanoviska), by bylo nějaké ucelenější pojednání o Aristotelově př́stupu $\mathrm{k}$ předchůdcům poměrně obsáhlé rozhodně obsáhlejší, než dovoluje formát odborného článku. V naší studii se proto zaměříme spíše pouze na jeden aspekt Aristotelova interpretačního př́stupu $\mathrm{k}$ předchůdcům, totiž na jeho numerickou kategorizaci předchůdců, respektive - abychom použili Aristotelovu terminologii - na to, o kolika principech jeho předchůdci hovořili.

I když je numerická kategorizace pouze jedním z interpretačních hledisek, s jejichž pomocí Aristotelés ke svým předchůdcům přistupuje, přesto lze bez nadsázky říci, že se jedná o jedno $z$ nejdůležitějších interpretačních hledisek, které je v nějaké podobě přítomno téměř vždy, když Aristotelés o svých předchůdcích hovoří. Jedná se o určité formální schéma či rozvržení, které prochází naprríč všemi jeho ostatními interpretacemi a které je mnohdy velmi nenápadným a subtilním způsobem ovlivňuje, ba zakládá. To např́íklad znamená, že Aristotelovo víceméně

${ }^{i}$ Např. Cherniss 1971. Srv. též Hobza 2004, Hobza 2005. 
stereotypní škatulkování Thaléta, Anaximena a Hérakleita jako monistů (jeden princip) a Empodoklea, Anaxagory a atomistů jako pluralistů (vícero principů), se v jeho pojetí jeví jako zcela samozřejmé východisko každého dalšího zkoumání, respektive každé další interpretace. ${ }^{\mathrm{i}}$

V naší studii se tedy pokusíme prozkoumat, jak Aristotelova numerická kategorizace (takřka jakožto určitý předběžný interpretační rozvrh) ovlivnila a předznamenala to, jak Aristotelés ke svým předchůdcům přistupoval, respektive jak a v čem mohla numerická kategorizace ovlivnit jeho interpretaci jejich myšlení. Nejprve však bude třeba prozkoumat samotnou numerickou kategorizaci - a to nejen s ohledem na to, jak ji Aristotelés sám přesně pojímal (zkoumání Aristotelovy numerické kategorizace vlastně ani jinak začít nelze), nýbrž i s ohledem na její původ (kdyby se totiž např́klad ukázalo, že ji Aristotelés nevytvořil, nýbrž převzal ze starší tradice, mohlo by srovnání Aristotelovy verze a její předlohy poskytnout vítané vodítko či východisko pro zkoumání, jak Aristotelovo pojetí

\footnotetext{
${ }^{\mathrm{i}}$ To, že je numerická kategorizace přítomná i v dalších interpretačních přístupech, je velmi dobře patrné např́íklad v první knize Metafyziky, která představuje Aristotelovo nejdelší a nejucelenější pojednání o předchůdcích. Aristotelés zde ke svým předchůdcům přistupuje $\mathrm{z}$ hlediska své koncepce čtyř příčin a snaží se zjistit, jaké druhy příčin se vyskytují v jejich myšlení, přičemž když je nahlíží prizmatem své látkové příčiny, tak jejich látkové principy zcela automaticky numericky kategorizuje (z hlediska látkové př́ičiny tak má Anaximanés jeden princip, zatímco Empedoklés čtyř).
} 
numerické kategorizace předznamenalo jeho interpretační př́stup $\mathrm{k}$ předchůdcům).

Nejnázorněji a nejexplicitněji pojednává Aristotelés o numerické kategorizaci ve druhé kapitole první knihy Fyziky. Pro názornost ocitujme celý text:

Phys. I, 2, 184b15-22

a) „Nutně je tedy bud' jeden princip (archén), anebo více.

b) Jestliže je jeden, je bud' nehybný, jak tvrdí Parmenidés a Melissos, anebo pohybující se, jak tvrdí prírodní filosofové, jedni považují za prvotní princip vzduch, jiní vodu.

c) Jestliže je principů více, je jich bud' omezený počet, anebo neomezený. Jestliže jich je omezený počet, avšak víc než jeden, bud' jsou dva, tři, čtyři nebo nějaký jiný počet; jestliže jich je neomezený počet, pak jsou bud' - jako u Démokrita - druhově totožné a liší se tvarem či formou, anebo jsou opačné. “i

Již při letmém přehlédnutí je zjevné, že Aristotelés své předchůdce nekategorizuje jednoduše podle toho, kolik principů kdo přesně postuluje, nýbrž $\mathrm{v}$ jeho kategorizaci se

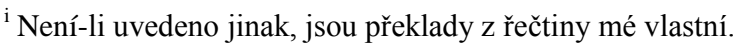


uplatňuje základní rozlišení a rozdělení předchůdců na ty, kdo postulovali pouze jeden princip, a na ty, kdo postulovali vícero principů, respektive na monisty a pluralisty.

Kromě tohoto základního rozdělení předchůdců na monisty a pluralisty implikuje Aristotelova numerická kategorizace ještě jedno důležité rozdělení - tentokrát $\mathrm{v}$ rámci skupiny monistů. Aristotelés totiž monisty dále rozděluje podle toho, zda svůj princip považovali za nehybný (akinétos) anebo pohybující se (kinúmené) (b). I když se toto rozdělení - důsledně vzato - netýká samotného numerického hlediska (nýbrž spíš pouze charakteru či povahy jediného principu), je důležité proto, poněvadž umožňuje rozlišit dva typy zcela odlišného zkoumání. Podle Aristotela je totiž pohyb (kinésis) základním znakem př́rody $(f y s i s)^{\mathrm{i}}$, takže rozdělení jednoho principu podle toho, zda se pohybuje nebo ne, souvisí s rozdělením předchůdců na ty, kdo se věnují zkoumání prírody, a na ty, kdo se věnují jinému (tj. metafyzickému) typu zkoumání. „Nuže zkoumat, zda to, co je (to on), je jedno a nehybné, není zkoumáním o prírodě.“ (Phys. I, 2, 184b25-185a1) Protože jsoucno, které stojí v centru zájmu eleatských myslitelů Parmenida či Melissa, vylučuje jakožto nehybné možnost jakékoli pohybu a změny, museli se eleatští

\footnotetext{
${ }^{\mathrm{i}}$ Srv. Met. V, 4, 1015a13-19; Phys. II,1 192b8-27.
} 
filosofové věnovat metafyzickému, a nikoli prrírodovědeckému zkoumání.

Jestliže vyloučíme ty monisty, kteří postulovali nehybný princip, zdá se, že se podle Aristotela ostatní předchůdci zabývali zkoumáním př́rody. Pokud jde o tyto př́rodní monisty a pluralisty, Aristotelés je dále rozlišuje podle druhu či kvality postulovaného principu, což je ovšem spíš sekundární hledisko, které slouží především k rozlišování jednotlivých předchůdců v rámci dané numerické kategorie. Třebaže v právě probírané pasáži z první knihy Fyziky uvádí Aristotelés za př́klad monistického principu pouze vzduch a vodu, z první knihy Metafyziky, která představuje jeho nejsystematičtější pojednání o předchůdcích, víme, že monistům připisoval ještě oheň, popř. jakýsi neurčitý střední prvek mající charakter něčeho mezi ohněm a vzduchem či mezi ohněm a vodou. Vodu považovali za princip podle Aristotela Thalés a Hippón (Met. I, 3, 983b20-984a5), vzduch Anaximenés a Diogenés z Apollónie (Met. I, 3, 984a5-7) a oheň zase Hippasos a Hérakleitos (Met. I, 3, 984a7-8). Pokud jde o onen neurčitý střední prvek, tak ten sice Aristotelés na několika místech zmiňuje v souvislosti s naukami monistů 
(např. Met. I, 7, 988a30; Met. I, 8, 989a14, atd.), avšak nikdy u něj neuvádí žádného konkrétního představitele. ${ }^{\text {i }}$

Pluralisty Aristotelés dále dělí jednak podle toho, kolik principů přesně postulovali, a jednak podle druhu či kvality jimi postulovaných principů. Není zcela jasné, kteří myslitelé podle Aristotela postulovali dva a tři principy ${ }^{\mathrm{ii}}$, nicméně čtyři principy Aristotelés běžně připisoval Empedokleovi (např. Met. I, 3, 984a8). Ti, kdo postulovali neomezený počet principů, je mohli podle Aristotela chápat - co do jejich druhu či kvality - bud' jako homogenní nebo heterogenní (opačné). Kvalitativně homogenní jsou Démokritovy atomy lišící se pouze tvarem, zatímco nekonečný počet kvalitativně heterogenních principů přisuzoval Aristotelés Anaxagorovi, který učil, že v každé částečce hmoty se nachází všechny existující prvky. Aristotelés ilustruje Anaxagorovu teorii látky na příkladu potravy: např́klad maso by mělo obsahovat částečky vlasů a kostí, nebot' když ho jíme, rostou nám vlasy a kosti (Aristotelés označoval Anaxagorovy prvky jako homoiomérie, resp. stejnodílné prvky) (srv. Phys. I,4 187a24-188a18).

\footnotetext{
${ }^{\mathrm{i}} \mathrm{K}$ problematice středního prvku a obecně k problémům, které Aristotelova numerická kategorizace vykazuje při aplikace na konkrétní předchůdce, viz Hobza 2005.

ii Parmenidés měl snad na mysli Parmenidovu přírodní filosofii (srv. Met. I,3 984b2-8), př́ípadně Platóna (srv. Met. I,6 987b14-988a17).
} 
Potom, co jsme blíže prozkoumali Aristotelovo pojetí numerické kategorizace, můžeme si položit otázku, zda s myšlenkou rozdělovat či kategorizovat předchůdce na základě numerického hlediska přišel až Aristotelés, anebo zda ji odněkud převzal. Již při letmém přehlédnutí dochovaných textů, je zjevné, že Aristotelés numerickou kategorizaci nevytvořil, nýbrž převzal. ${ }^{i}$ Přesto však nelze otázku původu Aristotelovy numerické kategorizace přejít pouze tímto konstatováním, nýbrž je třeba její původ důkladněji prozkoumat, nebot' - jak jsme již naznačili srovnání Aristotelova pojetí a původní předlohy může poskytnout důležité vodítko a východisko pro to, abychom porozuměli, jak Aristotelés své předchůdce chápal, respektive proč je interpretoval právě způsobem, jakým je interpretoval.

Se známým př́kladem numerické kategorizace se lze setkat hned u Aristotelova učitele, Platóna, v jeho dialogu Sofistés. Potom, co se začne zkoumání nejsoucna (mé on) poněkud zamotávat (Soph. 236d-241d), rozhodne se elejský cizinec prověřit platnost běžně přijímaných názorů, co se týče jsoucna (on). Již úvodní věta jeho zkoumání je pro naše téma signifikantní:

\footnotetext{
i Důkladný rozbor nejrůznějších interpretačních strategií v předaristotelském období lze nalézt v Mansfeld 1990.
} 
Soph. 242c4-6

„Zdá se mi, že s námi prŕlišs vlídně hovořil Parmenidés i každý, kdo se kdy rozhodoval o určování toho, kolik (posa) a jaká (poia) existují jsoucna (ta onta).“

Platón, resp. elejský cizinec, považuje tedy podobně jako Aristotelés za základní rys nauk svých předchůdců, na základě něhož lze tyto nauky kategorizovat, počet (,kolik“), prŕípadně druh či kvalitu (,jakác) postulovaných jsoucen. V následující pasáži je tato interpretační optika dále exemplifikována:

Soph. 242c8-243a1

„Zdá se, že každý nám vypráví jakýsi mýtus, jako bychom byli dětmi:

a) Jeden, že existují tři druhy jsoucen (tria ta onta), jednou některá z nich mezi sebou navzájem jaksi bojují, jindy zase uzavírají prátelství a sňatky a rodí a vychovávají potomky;

b) jiný zas hovoří o dvou, bud' vlhkém a suchém nebo teplém a chladném, a ty spolu snoubí a spojuje sňatkem;

c) avšak u nás je eleatský rod, pocházející od Xenofana, ba ještě z dřívějších dob, a ten vypráví 
tyto mýty tak, jako by to, co se nazývá vším, bylo jedním (hós henos ontos tón pantón kalúmenón).

d) Ale jakési jónské a sicilské Múzy si později uvědomily, že je nejspolehlivější spojit obojí a říci, že jsoucno je zároveň mnohé (polla) i jedno (en) a že je udržováno pohromadě svárem a láskou.

e) ,To, co se rozchází, se stále schází, říkají silnější z Múz.

f) Avšak slabší Múzy upustily od toho, že se toto děje nepřetržitě, a tvrdí, že se to děje postupně, jednou je vše (to pan) jedním díky prátelskému působení Afrodity a jindy je zase rozrůzněno do mnohých věcí (polla) a samo v sobě nepřátelské kvůli jakémusi sváru.“

Důvod, proč elejský cizinec pojímá nauky předchůdců jako jakési mýty, je ten, že předsókratici hovořili o různých jsoucnech (ta onta), aniž by však byli schopni odpovědět na to, co to jsoucno (to on) jako takové vůbec je (srv. Soph. 243d3-244b4). Ačkoli elejský cizinec zamýšlel kategorizovat nauky předchůdců jednak podle počtu a jednak podle druhu postulovaných jsoucen, přesto druhová kategorizaci (tj. kategorizace podle druhu postulovaného prvku) hraje na rozdíl od numerické kategorizace pouze doplňkovou či sekundární roli - elejský 
cizinec se o ní zmiňuje jen ve větě (b). Pokud jde o samotnou Platónovu numerickou kategorizaci, není (podobně jako u Aristotela) sice zcela jasné, kdo z předsókratiků hovořil o třech či dvou jsoucnech $(a, b)$, nicméně jedno jsoucno připisoval eleatům. Ve větách (d)(e), kde hovoří o tom, že jsoucno lze nahlížet jako jedno i jako mnohé, má na mysli patrně Hérakleita a Empedoklea, přičemž silnější Múzou je míněn patrně Hérakleitos (e), zatímco slabší Empedoklés (f).

I když by bylo lákavé předpokládat, že Aristotelés převzal numerickou kategorizaci od svého učitele, Platóna, přesto je při širším pohledu na dochované texty zjevné, že numerická kategorizace představovala $\mathrm{v}$ první polovině čtvrtého století poměrně běžnou optiku pro interpretaci či kategorizaci předsókratiků. Další důležitý doklad numerické kategorizace (který dokonce naznačuje, komu lze připsat dvě a tři jsoucna) se nachází v Ísokratově spisu Antidosis ${ }^{i i}$ :

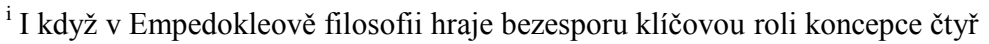
kořenů všech věcí (na něž především odkazuje Aristotelova numerická kategorizace), přesto je pro něj rovněž zásadní teorie světových cyklů, podle níž se počáteční jednota Sfaira rozpadá do mnohosti, v níž se teprve objevují čtyři kořeny věcí (srv. DK 31 B 17, kde se několikrát explicitně objeví téma střídání jednoty a mnohosti). Jak ukazuje pasáž z De gener. et corr. I, 1, 315a3-25, měl Aristotelés s touto Empedokleovou cyklickou koncepcí nepřekonatelné problémy. Platónův odkaz na silnější a slabší Múzy se týká toho, že zatímco Hérakleitos se domníval vše je zároveň jedno i mnohé, Empedoklés jedno a mnohé přisuzoval různým po sobě následujícím obdobím.

${ }^{i i} \mathrm{Na}$ rozdíl od Mansfelda považuji tuto pasáž za jedinou relevantní pasáž u Ísokrata o numerické kategorizaci, nebot' pasáž z Ísokratovy Heleny 3, kterou Mansfeld cituje jako další doklad numerické kategorizace, se snaží podle mého
} 
Antid. 268, 5-8

„Jeden tvrdil, že je nekonečné množství jsoucen;

Empedoklés zase že jsou čtyři a že v nich je láska a

svár;

Ión že jich není víc než tři;

Alkmeón že jsou pouze dvě;

Parmenidés a Mellisos že je pouze jedno

a Gorgias že není vůbec žádné.“

Podobné doklady numerické kategorizaci lze nalézt i v Xenofónových Vzpominkách na Sókrata, př́padně v pseudoaristotelském spise $O$ Mellisovi, Xenofanovi a Gorigiovi, kde se předsókratici rozdělují jen velmi schematicky na ty, kdo hovoří bud' o jednom jsoucnu, anebo o jejich nekonečném množství (Mem. I, 1, 14, 8-9), respektive na ty, kdo hovoří bud' o jednom anebo mnohém (MXG 979a16-17), aniž by zde ovšem byl nějaký myslitel uveden jménem. Avšak asi nejjasnější důkaz, že numerická kategorizace představovala v Aristotelově době vcelku běžnou interpretační optiku předsókratiků, nám poskytuje sám Aristotelés, když bezprostředně po výše citované pasáži z Fyziky (I, 2, 184b15-22) ř́ká:

názoru pouze poukázat na smělé či odvážné (srv. tolmésanta) koncepce jsoucna u Gorgii, Zenóna a Melissa, aniž by nějak explicitně odkazovala na numerickou kategorizaci (srv. Mansfeld 1990, s. 55-56). 
Phys. I, 2, 184b22-25

„Podobně zkoumají i ti, kteří zkoumají počet jsoucen. Zkoumají totiž, zda to, z čeho jakožto prvotního jsou věci složeny, je jedno či mnohé; a jestliže je mnohé, zda je ho omezený či neomezený počet. Lze tedy konstatovat, že zkoumají, zda je princip a prvek jeden či mnohý.“

Po tomto přehledu lze konstatovat, že Aristotelés numerickou kategorizaci nevytvořil, nýbrž převzal od svých předchůdců. I když se v další části naší studie pokusíme především prozkoumat, jak Aristotelés numerickou kategorizaci modifikoval, můžeme se ještě pro úplnost zamyslet nad jejím původem. Přehlédneme-li naše skrovné a kusé informace o předsókraticích, zdá se být zjevné, že numerická kategorizace prredstavuje vcelku prrirozený a logický prostředek, jak k jejich myšlení přistupovat. Někteří předsókratici totiž ve svých naukách prokazatelně uváděli číselné údaje (Empedoklés hovořil o čtyřech kořenech věcí, atomisti zase asi o nekonečném počtu atomů, zatímco eleaté trvali na existenci jediného jsoucna), takže myšlenka, že by toto numerické hledisko mohlo být možné uplatňovat obecně na všechny předsókratiky musela být víceméně nasnadě (byt' muselo být od počátku zjevné, že se do tohoto 
schématu nevejdou všichni předsókratici, např́klad pythagorejci, př́padně že někteří mohou z numerického hlediska působit jaksi ambivalentně, např́klad - jak o tom svědčí Platónova verze numerické kategorizace Hérakleitos a Empedoklés, u nichž se jaksi mísí monistické i pluralistické hledisko). Vzhledem k fragmentární evidenci nelze sice zjistit, kdo a $\mathrm{v}$ jaké podobě (př́padně $\mathrm{v}$ jakém kontextu) numerickou kategorizaci zavedl, nicméně je pravděpodobné, že numerická kategorizace představovala interpretační prostředek nejrůznějších kompendií a antologií, které se začaly objevovat koncem pátého století a jednu z nichž - jak se lze z určitých náznaků domnívat vytvořil patrně Hippias. ${ }^{\mathrm{i}}$

Nyní se můžeme konečně pokusit zamyslet nad tím, jak Aristotelés oproti svým předchůdcům numerickou kategorizaci modifikoval, což - jak jsme naznačili - nám může pomoci porozumět tomu, jak jeho numerická kategorizace mohla ovlivnit a poznamenat jeho chápání předchůdců. Již na první pohled je zjevné, že se Aristotelés od ostatních autorů liší v tom, co vlastně počítá, respektive co numericky kategorizuje. Zatímco ostatní hovořili o jsoucnech (onta), Aristotelés hovoří o principech (archai). Podíváme-li se letmo na nauky předsókratiků a na to, co v nich může být numericky kategorizována, je zjevné, že

\footnotetext{
${ }^{\mathrm{i}}$ Srv. KRS, s. 125, pozn. 17.
} 
označení jsoucna je více neutrální a přiměřenější intencím předsókratiků než Aristotelův poměrně silně systematicky zatížený pojem princip. Vzpomeňme si, že Empedoklés hovořil o čtyřech kořenech, atomisti zase o atomech, což jsou koncepce, které lze mnohem spíše a intuitivněji označit za jsoucna než za principy; nehledě na to, že eleaté hovořili explicitně o jsoucnu. Důvody, proč Aristotelés v souvislosti se svými předchůdci hovoří o principech, je třeba hledat v systematických souvislostech jeho filosofie. Podle Aristotela se totiž každé vědění (epistémé) musí zakládat na znalosti principů, takže i jeho předchůdci, kteří jakožto filosofové usilovali o vědění (a filosofie je podle Aristotela synonymem či ztělesněním vědění), museli postulovat nějaké principy. Jestliže se tedy Aristotelés zabývá svými filosofickými předchůdci, je pro něj vlastně zcela přirozené, že v jejich naukách hledá a nalézá principy.

At' už je ovšem Aristotelovo interpretační hledisko promítající do jeho předchůdců aristotelskou koncepci principů jakkoli důležité, v samotné numerické kategorizaci nehraje př́liš důležitou roli; jinými slovy, z hlediska samotné numerické kategorizace nepředstavuje Aristotelova záměna toho, co se numericky kategorizuje (tedy záměna jsoucen za principy), príliš důležitou modifikaci.

Zásadní modifikace tradiční numerické kategorizace, která má mnoho dalších dalekosáhlých 
implikací, spočívá naproti tomu v Aristotelově důsledném rozlišování předchůdců na monisty a pluralisty. $\mathrm{Na}$ základě uvedeného přehledu se sice zdá, že toto rozlišení mohlo být v nějaké podobě přítomné i u ostatních autorů, nicméně pokud zde bylo prítomno, tak pouze ve velmi vágním smyslu, který na rozdíl od Aristotelovy verze neměl na chápání předchůdců víceméně žádný dopad. Každopádně lze konstatovat, že v Platónově a Isokratově verzi numerické kategorizace (což jsou jediné obsáhlejší verze, které uvádějí i konkrétní myslitele) nehraje rozdělení na monisty a pluralisty v podstatě žádnou roli: Ísokratova verze představuje pouze jakýsi přehled či výčet předsókratiků podle počtu jsoucen; Platónova verze je sice poněkud sofistikovanější, nicméně ani zde nehraje rozlišení na monisty a pluralisty žádnou důležitější roli (pouze se zde naznačuje, že Hérakleitos a Empedoklés se domnívali, že jsoucno lze za určitých podmínek považovat za jedno i mnohé). Ve zbylých třech zmínkách (tj. u Xenofóna, v pseudoaristotelském spise $O$ Mellisovi, Xenofanovi a Gorigiovi a v Aristotelově shrnutí) se lze sice setkat s odkazem na rozdělení předsókratiků podle toho, zda hovořili o jednom anebo vícero jsoucnech, otázkou však je, zda je možné těmto zmínkám připisovat nějaké věcné implikace, a zda tedy nejsou pouze zcela formální charakteristikou. Uvědomíme-li si totiž, že na rozdíl od 
Platónovy a Ísokratovy verze nejsou ve zbylých třech zmínkách numerické kategorizace jmenováni žádní konkrétní myslitelé, a že se tudíž omezují pouze na konstatování, že předsókratici postulovali bud' jedno anebo vícero jsoucen, pak je vcelku oprávněné se domnívat, že tyto zmínky jsou pouze formální a nemají žádné věcné implikace. Jestliže se však nad těmito třemi zmínkami zamyslíme ještě o něco důkladněji, můžeme jít dokonce ještě dál a konstatovat, že tyto zmínky (o tom, že předsokratici postulovali bud' jedno anebo vícero jsoucen) vposled nepředstavují ani odkaz na nějaké formální rozdělení předsókratiků na monisty a pluralisty, nýbrž že jsou vlastně pouhým označením či pojmenováním toho, co my zde označujeme jako numerická kategorizace. Jinými slovy, jestliže výše uvedení autoři ř́ḱkali něco v tom smyslu, že „někteří myslitelé postulují jedno jsoucno, zatímco jíní vícero jsoucen“, tak se vlastně nejedná o nic jiného než o obrat, který mi překládáme či opisujeme pomocí obratu „numerická kategorizace“.

Jestliže tomu tak skutečně je a jestliže tedy tradiční verze numerické kategorizace nijak explicitně nepracovala s rozlišením na monisty a pluralisty, můžeme se tím spíše pustit do zkoumání této zásadní Aristotelovy modifikace. První věc, nad kterou je třeba se zamyslet, je, proč Aristotelés přikládal rozlišení na monisty a pluralisty 
takový význam, jaký mu přikládal. Na první pohled by se mohlo zdát, že to souvisí s důležitostí, jakou má ve filosofii téma jednoty a mnohosti, respektive s důležitostí, kterou mělo v řeckém myšlení číslo jedno. Při bližším pohledu je však zjevné, že pro Aristotela mělo rozlišení předchůdců na monisty a pluralisty mnohem hlubší a systematičtější založení. Podle Aristotela totiž souvisí rozdělení na monisty a pluralisty sodlišným vysvětlením vzniku a zániku. Tomuto problému se věnuje především ve spise $O$ vniku $a$ zániku:

De gener. et corr. I, 1, 314a6-13

a) „Ze starých myslitelů jedni tvrdí, že takzvaný naprostý vznik (haplén genesin) je kvalitativní změnou (alloiósin), druzí však, že kvalitativní změna a vznik jsou odlišné.

b) Ti totiž, kteří se domnívají, že všechno je jakési jedno a že všechny věci vznikají z jedna, musí také tvrdit, že vznik je kvalitativní změnou a že to, co ve vlastním smyslu vzniká, se pouze kvalitativně mění. c) Ti však, kteří př́edpokládají, že látka je víc než jedna, např. Empedoklés, Anaxagoras a Leukippos, musí zase předpokládat, že jsou odlišné.“i

\footnotetext{
${ }^{\mathrm{i}}$ Upravený překl. M. Mráz.
} 
Monisti (b), kteří se domnívají, že vše se skládá pouze z jediného prvku či jediného typu látky (např. vody či vzduchu), musí chápat veškerý vznik jednotlivých věcí pouze jako kvalitativní změnu jediného prvku, „nebot' podklad (to hypokeimenon) musí zůstávat vždy tentýž a jeden; a o něm říkáme, že se kvalitativně mění.“ (De gener. et corr. I, 1, 314b3-4) (Připomeňme, že to, co Aristotelés nazývá kvalitativní změnou, není nic jiného zhuštování a zřed'ování.) Pluralisti, kteří považují vznik a kvalitativní změnu za odlišné věci (c), vysvětlují vznik jako slučování, respektive míšení, a rozlučování různých prvků:

De gener. et corr. I, 1, 314b4-8

„Ale podle těch, kteří uznávají vícero druhů [prvků], se kvalitativní změna musí lišit od vzniku - nebot' vznik a zánik se děje tak, že se [prvky] slučují a rozlučují. Proto v tomto smyslu říká také Empedoklés, že neexistuje přirozený vznik ničeho, nýbrž jen míšení a rozlučování smíšených věcí.“i

Podle Aristotela tedy prrírodní filosofové vysvětlují vznik a zánik dvojím způsobem, přičemž jejich vysvětlení se liší podle toho, zda postulují jeden princip anebo více. Tímto rozlišením prrírodních filosofü podle toho, jak

\footnotetext{
${ }^{\mathrm{i}}$ Upravený překl. M. Mráz.
} 
vysvětlovali vznik a zánik, ovšem Aristotelés zároveň propůjčil numerické kategorizaci, která původně nebyla ničím víc než jen prostř̌edkem pro výčet či přehled jednotlivých myslitelů, zcela nový a významuplný rozměr. Počet principů má tedy v aristotelské optice zásadní vliv na charakter myšlení toho kterého myslitele, respektive na to, jak kdo pojímal tak (zvláště pro Řeky) zásadní filosofický problém, jakým je vysvětlení způsobu, jak věci vznikají a zanikají (zda na základě kvalitativní změny nebo slučování a rozlučování). Jinými slovy, Aristotelská interpretační optika může vnést do myšlení toho kterého myslitele problémy, které jsou pro jeho myšlení zcela neadekvátní. ${ }^{i}$

Na pozadí této Aristotelovy modifikace, je zjevné, proč Aristotelés musel skupinu monistů rozdělit do dvou skupin. Jestliže Aristotelovo pojetí numerické kategorizace (zakládající se na rozdělení monistů a pluralistů) bytostně souvisí s prrírodovědným problémem, jak vysvětlovat vznik a zánik, a jestliže je tak i její založení vlastně př́rodovědné,

\footnotetext{
${ }^{\text {i } U v e ̌ d o m i ́ m e-l i ~ s i, ~ z ̌ e ~ i ~ p o u h y ́ ~ v y ́ c ̌ e t ~ c ̌ i ~ p r ̌ e h l e d ~ m y s l i t e l u ̊, ~ k t e r y ́ ~ p o d a ́ v a ́ ~ p u ̊ v o d n i ́ ~}$ verze numerické kategorizace, může být sám o sobě velmi závažným a obtížně ospravedlnitelným interpretačním krokem (nebot' znamená zařazení odlišných myslitelů do jedné skupiny a do jedné interpretační perspektivy), tak Aristotelovu optiku by bylo možné z historického hlediska považovat jednoduše za desinterpretaci. Pokud jde o to, jak může např́íklad toto Aristotelovo rozdělení předsókratiků podle toho, jak podle Aristotela měli vysvětlovat vznik, srv. především De gener. et corr. I, 1, 314a13-16, kde Aristotelés o Anaxagorovi explicitně ř́íá, že neporozuměl vlastní výkladu, nebot' přesto, že je pluralista, který měl chápat vznik jako slučování a rozlučování, ho chápal jako kvalitativní změnu, a tudíž jako monista.
} 
tak v ní nezbývá př́iliš mnoho místa pro jiný, např́klad metafyzický, způsob zkoumání. Nechtěl-li tedy Aristotelés vyloučit eleaty z numerické kategorizace, a tak je vlastně zcela oddělit a izolovat od ostatních předsókratiků, musel monisty rozdělit do dvou skupin - podle toho, zda lze jejich principu prripsat pohyb (a tak ho považovat za součást přírodovědného zkoumání) anebo nelze (a tak ho nahlížet jako předmět metafyzického zkoumání). I když nám dnes může prripadat toto aristotelské rozlišení vcelku samozřejmé, je třeba si uvědomit, že Aristotelovým současníkům se tak samozřejmým jevit nemuselo. Jak o tom svědčí uvedené doklady numerických kategorizací, na přelomu pátého a čtvrtého století mohl být za hlavní rozdíl mezi eleaty a ostatními předsókratiky považován jednoduše počet principů (byt' i to není tak jasné, nebot' např́klad Platón ve výše uvedeném citátu z dialogu Sofistés naznačuje, že Hérakleitos a Empedoklés ve svém myšlení nějak spojují monismus a pluralismus). I když se může zdát, že rozdíl mezi eleaty a ostatními předsókratiky nemusel být tak velký, jak naznačuje Aristotelés, přesto by bylo jistě nesprávné, kdybychom se ho snažili úplně setřít či relativizovat. Na druhou stranu je třeba si hned uvědomit, že Aristotelovo rozlišení na ty, kdo se věnují prírodním zkoumání, a na ty, kdo metafyzickému, je do značné míry extrémní. Aristotelés totiž nejenže říká, že mezi eleaty a 
ostatními předsókratiky existuje rozdíl, nýbrž v podstatě naznačuje, že rozdíl mezi nimi je tak velký a zásadní, že je vlastně nelze ani nijak srovnávat, protože nemají mezi sebou nic společného, co by se mohlo stát základem pro jejich srovnání. Připomeňme si, že v Aristotelově pojetí spočívá rozdíl mezi eleaty a ostatními předsókratiky jednak ve způsobu zkoumání (metafyzický versus př́rodovědný) a jednak v odlišném předmětu, na který se jejich myšlení vztahovalo (nehybný versus pohyblivý princip), takže v podstatě nezbývá žádný společný bod, na jehož základě by je bylo možné nějak smysluplně srovnávat. $Z$ tohoto hlediska se jeví jako mnohem přijatelnější a plodnější přístup Platónův, který např́klad $\mathrm{v}$ dialogu Theiaitétos nemá žádný problém s tím, aby srovnával eleaty s ostatními předsókratiky, reprezentovanými především Hérakleitem (srv. Tht. 152e; 179e-184b). Podle Platóna se obě skupiny myslitelů lišili pouze $\mathrm{v}$ tom, jak chápali povahu jsoucna bud' ho považovali za něco neměnného anebo naopak za něco neustále se proměňujícího; jinak řečeno, obě skupiny se vztahují ke stejnému předmětu (jsoucnu či světu) a pouze jinak interpretují jeho povahu. ${ }^{\mathrm{i}}$

\footnotetext{
${ }^{\mathrm{i}}$ Ačkoli se tato kategorizace eleatů a ostatních předsókratovských filosofů podle podle schématu nehybné versus pohybující se, respektive neměnné versus měnící se, nevyskytuje v citovaných numerických kategorizacích u Platóna a Isokrata, u Xenofóna a v pseudoaristotelském spise $O$ Mellisovi, Xenofanovi a Gorigiovi, které jsme výše zmínili pouze letmo v souvislosti s počtem principů, je toto schéma (nehybné versus pohybující se) uváděno v těsné souvislosti
} 
Se skupinou monistů, tentokrát př́rodních (tedy těch, kdo podle Aristotela postulovali jeden pohybující se princip), však možná souvisí ještě jedna důležitá Aristotelova modifikace, která se netýká ničeho menšího než toho, že Aristotelés jednoduše tuto skupinu uměle vytvořil na základě svého interpretačního hlediska. Vzhledem k naší fragmentární textové evidenci si sice nemůže být úplně jisti, do jaké míry se jedná skutečně o Aristotelovu konstrukci, nicméně spojíme-li si různé stř́ípky naší evidence dohromady, můžeme se skutečně důvodně domnívat, že skupina př́rodních monistů (tak jak ji Aristotelés koncipuje) představuje čistě Aristotelův interpretační výtvor.

První věc, která je v této souvislosti nápadná, je to, že $\mathrm{v}$ původních verzích numerických kategorizací se za monisty považují výhradně eleaté, což by mohlo naznačovat, že nikomu jinému nebyl připisován jeden prvek. Vzhledem k tomu, že se můžeme opř́t pouze o dva doklady (Platóna a Ísokrata), nelze toto svědectví príliš přeceňovat. Ukázalo-li by se však, že celá Aristotelova koncepce př́rodních monistů vykazuje při bližším pohledu trhliny, tak by to mohlo jen posílit naše podežrení, že celá tato skupina je pouze Aristotelovou interpretační

s numerickou kategorizací, snad jako určité doplňující hledisko (srv. Mem. I, 1, 14, 9-10; MXG 979a17-18). 
konstrukcí. (To by mohlo mít zásadní vliv na myšlení těch, které Aristotelés kategorizuje jako monisty, nebot' vzhledem k Aristotelovu vlivu by to mohlo i dnes vnášet do jejich myšlení hlediska a problémy, které byly jejich vlastnímu myšlení zcela cizí.) Proto se pokusme důkladně prozkoumat Aristotelovu koncepci prírodních monistů, přičemž se nejprve podívejme na to, jak ji Aristotelés koncipuje, a poté na to, jaké myslitele považuje za přírodní monisty, respektive na to, zda myšlení těchto myslitelů alespoň na základě naší fragmentární textové evidence odpovídá charakteristikám, na jejichž základě Aristotelés koncipuje skupinu prŕŕrodních monistů.

Jak jsme viděli, základní charakteristikou skupiny monistů je podle Aristotela jednak to, že postulovali jeden prrírodní či materiální (protože pohybující se) princip, a jednak to, že z tohoto principu na základě kvalitativní změny (tedy na základě zhuštování a zřed’ování) vzniká svět. Jinými slovy, Aristotelés př́rodní monisty charakterizuje na základě jednoduchého schématu: z jednoho principu vzniká na základě kvalitativní změny svět. Pokud jde o konkrétní myslitele, které Aristotelés mezi prrírodní monisty řadí, jsou to dva mílétští myslitelé, Thalés a Anaximenés ${ }^{i}$ a kromě nich ještě především Hérakleitos a

\footnotetext{
i Je zajímavé, zároveň však signifikantní, že Aristotelés neřadí mezi monisty Anaximandra. Naopak ho explicitně chápe jako pluralistu a navíc mu nikde explicitně nepřipisuje koncepci apeironu. Byl to až Aristotelův žák, Theofrastos,
} 
Diogenés z Apollónie, prričemž Thalétovi připisuje jako princip vodu, Anaximenovi vzduch, Hérakleitovi oheň a Diogenovi vzduch, což ho činí nápadně podobným Anaximenovi (srv. Met. I,3 983b20-984a8). ${ }^{\mathrm{i}}$

Vzhledem k tomu, že se nám od Mílét'anů nedochovaly takřka žádné prímé zprávy, respektive autentické citáty zjejich děl, které by nám umožnily potvrdit, zda lze u nich ono výše uvedené monistické schéma skutečně nalézt, představují Hérakleitos a Diogenés jedinou možnost, jak ověřit, zda (či do jaké míry) je Aristotelova koncepce prírodních monistů jeho interpretační konstrukcí, př́padně zda (či do jaké míry) je skutečně odvozena z myšlení těch, které Aristotelés mezi prírodní monisty řadí. ${ }^{i}$ Podíváme-li se nejprve na dochované zlomky z Hérkaleita, brzy zjistíme, že zde pro Aristotelovo monistické schéma (jeden materiální princip, z něhož na základě kvalitativní změny vzniká svět) nelze nalézt takřka žádnou oporu. Hérakleitos sice skutečně mluví o ohni, avšak rozhodně ho nechápe jako materiální princip, z něhož

kdo Anaximandra chápal jako monistu a připisoval mu koncepci apeironu. K tomuto problému viz Hobza 2004.

${ }^{\mathrm{i}}$ Kromě nich mezi monisty řadí ještě Hippasa z Metapontu, kterému podobně jako Hérakleitovi připisuje oheň, avšak vzhledem k tomu, že se nám o něm dochovalo jen velmi málo informací, tak se jím nebudeme zabývat.

${ }^{\text {ii }}$ Srv. KRS, s. 17: „Plná důvěra v naše porozumění určitému předsókratovskému mysliteli je tedy oprávněná pouze tam, kde aristotelskou nebo theofrastovskou interpretaci - i tam, kde ji můžeme přesně rekonstruovat potvrzují příslušné a prokazatelně autentické výňatky z tohoto filosofa samého.“ 
by vznikal svět. Oheň je v jeho pojetí spíš symbolem neustálé změny a proměny; spíš než jeho fyzický či materiální aspekt zajímá tedy Hérakleita jeho nestálé, frenetické plápolání a přeskakování. Navíc vzhledem ke komplexnosti Hérakleitova myšlení nelze koncepci ohně považovat za koncepci, kterou by bylo možné oddělit, ba izolovat od ostatních částí jeho myšlení (podobně jako lze oddělit např́klad nějaký fyzikální problém od jiného, př́padně od metafyzického problému). Naopak, oheň představuje pouze jeden z mnoha Hérakleitových pojmů, které na sebe navzájem odkazují a doplňují se a kolem kterých se jeho myšlení utváří a rozvíjí. Takže i když každý z těchto pojmů odhaluje pouze určitý aspekt světa, ve svém souhrnu dávají možnost uchopit svět $v$ celé jeho komplexnosti. Mezi tyto další klíčové pojmy a koncepce Hérakleitova myšlení patří např́íklad logos (srv. DK 22 B 1, B 2), boj (polemos, srv. B 53, B 80), jednota protikladů (srv. DK 22 B 10; B 60), skrytá harmonie (srv. B 54), respektive harmonie toho, co je v rozporu (srv. B 8), moudré (sofon, srv. B 32; B 41; B 50), společné (xynon, srv. B 2; B 114) atd. Kdybychom však chtěli Hérakleitovo myšlení i přes tyto výhrady nějak numericky kategorizovat, jevila by se mnohem přijatelněji Platónova výše uvedená interpretace Hérakleita jako toho, kdo považuje jsoucna za jedno a zároveň za mnohé - pro což lze (na rozdíl od 
aristotelského monismu) nalézt i poměrně dobrou oporu v Hérakleitových zlomcích (srv. DK 22 B 10; B 50).

Ani Diogéna z Apollónie nelze ovšem jednoduše pokládat za prrírodního monistu aristotelského typu, třebaže k němu má přece jen blíž než Hérakleitos. Aristotelés (a spolu s ním i většina moderních badatelů) se sice domnívá, že Diogenés považoval za materiální princip vzduch, ${ }^{\mathrm{i}}$ nicméně při trochu bližším pohledu se ukazuje, že Diogenés vzduch spíše spojoval s duší a myšlením (DK 63 B 4) a chápal ho analogicky k činnosti kormidelníka jako jakýsi organizační princip všech věcí (DK 63 B 5). Jinými slovy, vzduch nelze považovat jednoduše za materiální princip, z něhož vzniká svět. To, z čeho svět vzniká (z čeho se skládá), je naproti tomu podle Diogena nějaká základní, blíže neurčená látka, jejíž přeměnou (eteroiústhai) vznikají základní živly (země, voda, vzduch a oheň) a ostatní věci; proto může Diogenés říci, že všechny věci se přeměňují z téhož a jsou tímtéž (panta ta onta apo tú autú eteroiústhai kai to auto einai, DK 63 B 2). Diogenovu filosofickou koncepci tedy rozhodně nelze ztotožňovat $\mathrm{s}$ aristotelským monismem, a to hned z několika důvodů: 1) Na rozdíl od aristotelské monistické koncepce Diogenés hovoří spíše o dvou věcech či principech - jednak o vzduchu jako o

\footnotetext{
${ }^{\mathrm{i} I}$ v současné literatuře se jedná o běžnou a takřka stereotypní představu, kterou kterou však velmi plausibilně zpochybnil Barnes 1982, s. 574-576: srv. „,his arche is not air (...); it is matter, stuff."
} 
určitém oduševnělém a organizačním principu a jednak o jakési neurčité látce, která je nějak organizována vzduchem. 2) Ale i kdybychom se zaměřili na Diogenovu koncepci látky, ani ta zcela neodpovídá Aristotelově monistické konstrukci. Pro Aristotelův monistický princip je charakteristické, že se jedná o nějaký konkrétní prvek (např. oheň, vzduch, voda), který se může kvalitativně měnit na jiné prvky, ale výchozí prvek či princip je v přeměně jaksi neustále př́tomný (kdyby se totiž $\mathrm{v}$ přeměněné věci zcela vytratila identita výchozího prvku, tak by se nemohlo jednat pouze o kvalitativní změnu, nýbrž spíš o substanční změnu). Diogenovo pojetí látky si však žádnou výchozí identitu neuchovává, nýbrž - jak Diogenés explicitně říká - všechny věci jsou totožné (srv. DK 63 B 2). Jinými slovy, Diogenovo pojetí látky se spíš podobá Platónově charakteristice Hérakleita (tedy že se jeví jako jedno a zároveň mnohé) než aristotelské monismu. 3) Obecně lze říci, že Diogenovo myšlení má mnohem blíže $\mathrm{k}$ Anaxagorovi než $\mathrm{k}$ aristotelské představě monismu. Diogenés pouze nahradil Anaxagorovu Mysl, pojímanou jako nejjemnější hmotu, svou koncepcí vzduchu; a zatímco Anaxagoras hovořil $\mathrm{v}$ souvislosti s hmotou o semenech věcí, protikladech a jejich míšení, Diogenés ji koncipoval jako totožnou (to auto) a přeměňující se (eteroiústhai). ${ }^{\mathrm{i}}$

\footnotetext{
i Jedním z důvodů, proč mohlo Aristotelovi připadat jako samozřejmé řadit
} 


\section{Uvážíme-li tedy na závěr problémy spojené $\mathrm{s}$ aristotelskou koncepcí prírodních monistů a spojíme-li je s tím, že v dobovém kontextu se jeden princip či jeden}

Diogena mezi monisty, mohla být i Diogenova koncepce přeměny (eteroiústhai). Tento důvod plně vynikne na pozadí Aristotelova chápání Anaxagory. I když ho Aristotelés stereotypně řadí mezi pluralisty, přesto jakoby měl s tímto zařazením někdy problémy, ba jako by někdy dokonce naznačoval, že by Anaxagoras mohl být považován spíš za monistu. V této souvislosti jsou signifikantní především dvě pasáže: 1) V Met. I,8 989a30-b21 zvažuje možnost, že Anaxagoras hovoří pouze o dvou prvcích či principech (Mysli a látce), takže toto hledisko potlačuje Anaxagorovo pojetí hmoty jako pluralistické směsi nekonečně mnoha principů, respektive stejnodílných prvků, a naopak naznačuje, že Anaxagorovu hmotu lze chápat monisticky. 2) V De gener. et corr. I, 1, 314a13-16 zase Aristotelés naznačuje, že Anaxagoras vysvětloval vznik jako kvalitativní změnu (alloiósis). A protože kvalitativní změna je typicky monistickým způsobem vysvětlení vzniku a zániku, je zjevné, že Aristotelés naráží na to, že Anaxagorovo zařazení mezi pluralisty není úplně bez problémů. Důvod, proč i přes tyto problémy pojímá Anaxagoru především stereotypně jako pluralistu, spočívají asi zejména v tom, že Anaxagoras pojímá látku jako směs. A směs je podle Aristotela zase typicky pluralistická koncepce, která implikuje pojetí vzniku jako slučování a rozlučování, respektive směšování a rozměšování, což jsou všechny pojmy a koncepce se kterými Anaxagoras explicitně pracuje (srv. DK 59 B 12). (Důvody, proč Aristotelés vůbec zvažuje možnost, že by Anaxagoras vysvětloval vznik jako kvalitativní změnu, souvisí s velmi specifickým pojetím Anaxagorovy látky, respektive její nekonečnou dělitelností, která vposled vylučuje možnost nějakých základních, neměnných a nedělitelných prvků či principů, které jsou zase předpokladem Aristotelovy interpretační optiky; jinými slovy, jestliže je látka nekonečně dělitelná, a jestliže tudíž neexistují žádné pevné prvky, pak je otázka, zda lze vůbec hovořit o nějaké směsi.) Vrátíme-li se po těchto úvahách $\mathrm{k}$ Diogenovi a jeho koncepci přeměňující se látky, lze konstatovat, že Aristotelés mohl tuto koncepci poměrně snadno ztotožnit se svou koncepcí kvalitativní změny (oba řecké termíny alloiósis a eteroiústhai, pocházející z adjektiv allos a eteros, které znamenají ,jiný“', jsou v podstatě synonymní). A protože kvalitativní změna je typická monistická koncepce, mohl Aristotelés již díky tomuto jedinému termínu považovat Diogena za monistu. Uvážíme-li, jak schématicky a neadekvátně interpretuje Aristotelés např́íklad Hérakleita, pak by takový závěr nebyl nijak překvapivý. 
prvek připisoval pouze eleatům ${ }^{\mathrm{i}}$, pak se myšlenka, že Aristotelés tuto skupinu jednoduše vytvořil, nemusí zdát prŕliš přehnaná. Pokud ale Aristotelés tuto skupinu skutečně vytvořil (na základě určitých systematických interpretačních posunů při koncipování své verze numerické kategorizace), pak by mohl mít tento Aristotelův interpretační čin dalekosáhlé důsledky především pro naše porozumění Mílétanům, protože od nich se nám nedochovaly žádné autentické texty, které by umožnily Aristotelovu interpretaci ověřit, prípadně upravit. Mílét’anům je totiž běžně podsouvána koncepce pralátky, respektive nějakého materiálního principu, $\mathrm{z}$ něhož na základě zhuštování a zřed'ování vzniká svět, což je koncepce, které se velmi podezřele podobá právě Aristotelovu monistickému schématu. Jestliže však Aristotelés své monistické schéma připisuje všem přírodním monistům a jestliže ho - jak se ukázalo - velmi násilně a nepatřičně vnucuje Hérakleitovi a Diogenovi, tak se lze obávat, že ho možná stejně násilně a nepatřičně vnutil i

\footnotetext{
${ }^{i}$ Pokud je mi známo, tak za jediný doklad, který by mohl potvrzovat obecněji uznávanou existenci skupiny př́rodních monistů před Aristotelem, by bylo možné považovat hippokratovský spis $O$ lidské přirozenosti, na jehož začátku se autor vymezuje proti těm, kteři hovoří pouze o jednom prvku (vzduchu, ohni, vodě či zemi). Nicméně vzhledem ke specifickému lékařskému kontextu a tomu i přizpůsobené argumentaci nelze tento doklad příliš přeceňovat, nebot' autor nemusí mít nutně na mysli ty, kdo vysvětlují svět na základě jednoho prvku, nýbrž pouze ty lékaře, kteří předpokládali, že člověk je konstituován především jedním prvkem (a připomeňme, že tento hippokratovský autor se domníval, že člověk je konstituován čtyřmi základními tělesnými tekutinami).
} 
Mílét’anům ${ }^{\mathrm{i}}$, čímž mohl do značné míry vytvořit i mýtus o mílétském hledání pralátky. Bylo by snad sice možné argumentovat, že Aristotelés toto schéma našel právě u Mílét’anů (respektive především u Anaximena) a od nich ho rozširríil i na další myslitele, nicméně stejně dobře a přesvědčivě by bylo možné argumentovat, že toto schéma představuje čistě Aristotelovo interpretační hledisko, které vyplývá z jeho koncepce numerické kategorizace, respektive z jeho systematického rozdělení na monisty a pluralisty. (Abychom si uvědomili zkreslení, které by př́ípadné vnucení aristotelské monistické optiky, respektive koncepce pralátky, mohlo mít na mílétské myšlení, stačí si jen uvědomit, jak by taková monistická optika zcela zdeformovala Hérakleitovo myšlení. A není žádný důvod se domnívat, že by mílétské myšlení mělo být podobnější Aristotelově monistické koncepci než právě Hérakleitovu myšlení.)

\footnotetext{
i Tedy především Thalétovi a Anaximenovi, protože - jak jsme naznačili v poznámce 15 - Anaximandra považoval za pluralistu. Nicméně tím, že Theofarastos učinil i z Anaximandra prrírodního monistu, lze konstatovat, že ve výsledku ovlivnilo Aristotelovo monistické schéma všechny Mílét’any.
} 


\section{AIOHP III.5}

Bibliografie:

J. Barnes, 1982, The Presocratic Philosphers, London, New York.

H. Cherniss, 1971, Aritotle's Criticism of Presocratic Philosophy, New York.

P. Hobza, 2004, „Aristotelés a Theofrastos jako tvůrci mílétské filosofie“, in: Filosofický časopis 6, s. 889-924.

P. Hobza, 2005, „Střední prvek a Aristotelova katalogizace přírodních filosofư", in: Reflexe 27, s. 51-74.

J. Mansfeld, 1990, „Aristotle, Plato, and the Prepaltonic Doxography and Chronography", in: Studies in the Historiography of Greek Philosophy, Assen, Maastricht.

\section{Zkratky:}

KRS - Kirk, G. S., Raven, J. E., Schofield, M, Předsókratovští filosofové, Praha 2004.

DK - Diels, H., Kranz, W., Die Fragmente der Vorsokratiker, Dublin, Zürich 1969.

Aristotelés

De gener. et corr. - De generatione et corruptione (O vzniku a zániku)

Met. - Metaphysica

Phys. - Physica

Ísokratés

Antid. - Antidosis 


\author{
Platón \\ Soph. - Sophista \\ Tht. - Theatetus
}

Pseudo-Aristotelés

MXG - De Melisso Xanophane Gorgia

Xenofón

Mem. - Memorabilia (Vzpomínky na Sókrata) 